NOTICE: this is the author's version of a work that was accepted for publication in Chemical Geology. A definitive version was subsequently published in Chemical Geology 419, 118-124, 2015.

http://dx.doi.org/10.1016/j.chemgeo.2015.05.013

(C) 2015, Elsevier. Licensed under the Creative Commons Attribution-NonCommercial-NoDerivatives 4.0 International http://creativecommons.org/licenses/by-nc-nd/4.0.

\title{
The impact of fluoride on Al abundance and speciation in boreal streams
}

Tobias Berger $^{a^{*}}$, Frédéric Mathurin ${ }^{a}$, Jon Petter Gustafsson ${ }^{b, c}$, Pasi Peltola , Mats Erik Åström ${ }^{\mathrm{a}}$

${ }^{a}$ Department of Biology and Environmental Science, Linnaeus University, SE-391 82 Kalmar, Sweden

bDepartment of Soil and Environment, Swedish University of Agricultural Sciences, Box 7014, SE-750 07 Uppsala, Sweden

'Division of Land and Water Resources Engineering, KTH Royal Institute of Technology, SE10044 Stockholm, Sweden

*Corresponding author. Tel: +46 4804473 84. E-mail address: tobias.berger@Inu.se 


\title{
The impact of fluoride on Al abundance and speciation in boreal streams
}

\author{
Tobias Berger $^{\mathrm{a}^{*}}$, Frédéric A. Mathurin ${ }^{\mathrm{a}}$, Jon Petter Gustafsson ${ }^{\mathrm{b}, \mathrm{c}}$, Pasi Peltola ${ }^{\mathrm{a}}$, Mats E. \\ Åström ${ }^{\mathrm{a}}$
}

${ }^{a}$ Department of Biology and Environmental Science, Linnaeus University, SE-391 82 Kalmar, Sweden

${ }^{\mathrm{b}}$ Department of Soil and Environment, Swedish University of Agricultural Sciences, Box 7014, SE-750 07 Uppsala, Sweden

${ }^{\mathrm{C}}$ Division of Land and Water Resources Engineering, KTH Royal Institute of Technology, SE10044 Stockholm, Sweden

*Corresponding author. Tel: +46 4804473 84. E-mail address: tobias.berger@Inu.se

The impact of fluoride on the abundance and speciation of aluminium (Al) was investigated in three boreal streams characterised by overall high concentrations of fluoride and dissolved organic matter. Stream-water sampling was carried out several times a year for at least four years, and a chemical equilibrium model (Visual MINTEQ) was applied in order to model the proportion of colloidal and organically/inorganically complexed $\mathrm{Al}$ in the waters. The Al concentrations in filtered $(0.45 \mu \mathrm{m})$ water samples were inversely correlated with $\mathrm{pH}$, and reached values up to approximately $1 \mathrm{mg} / \mathrm{L}$ during low $\mathrm{pH}$ conditions $(\mathrm{pH}<6.0)$. In a stream with high fluoride concentrations, as compared to a similar stream with only moderately elevated fluoride concentrations, the Al concentrations were consistently elevated. For the stream with high concentrations of fluoride and Al, the model predicted both high concentrations and proportions of Al-fluoride complexation. This prediction indicates that high fluoride levels contribute to raise both the Al abundance and the ratio of inorganic to organic Al complexation in stream water. In contrast, for another stream with high fluoride concentrations and consistently high (near neutral) $\mathrm{pH}$, there was no evidence of fluoride affecting $\mathrm{Al}$ concentration or complexation. These results show that it is important to focus future studies on the role of high levels of dissolved fluoride on both the speciation and the toxicity of $\mathrm{Al}$ in stream water.

Keywords: aluminium, fluoride, Al speciation, boreal catchments, chemical modelling, Al toxicity

\section{Abbreviations:}

$\mathrm{Al}_{0.45}=\quad$ Analytical data of aluminium after filtration by a $0.45 \mu \mathrm{m}$ pore size membrane filter (i.e., excluding particulate Al)

$A \mathrm{I}_{\mathrm{c}}=\quad$ Modelled inorganic colloidal aluminium, i.e., the proportion of $\mathrm{Al}_{0.45}$ occurring as $\mathrm{Al}(\mathrm{OH})_{3}(\mathrm{~s})$

$\mathrm{Al}_{\mathrm{i}}=\quad$ Modelled inorganic monomeric aluminium, i.e., the sum of aquo, hydroxy and other inorganically complexed forms

$A I_{i-F}=\quad$ Modelled fluoride-complexed aluminium

$\mathrm{Al}_{\mathrm{O}}=\quad$ Modelled organically complexed aluminium

$A l_{d}=\quad$ Modelled dissolved aluminium, i.e., $\mathrm{Al}_{i}+\mathrm{Al}_{\mathrm{o}}$ (all dissolved $\mathrm{Al}$ species are listed in Tables A2-A3, Appendix A) 


\section{Introduction}

The effect of dissolved fluoride on Al toxicity is complex and ambiguous. Although fluoride complexes of Al are sometimes proposed to mitigate Al toxicity to some extent in comparison to other inorganic Al complexes, they still represent a bioavailable and thus possibly toxic fraction in comparison to organically bound Al (Bi, 2001; Deng et al., 2011; Frankowski and Ziola-Frankowska, 2010; Gensemer and Playle, 1999; Haag et al., 2001). Modelling work has suggested that fluoride can potentially be important in controlling the presence and speciation of monomeric Al in surface waters (Sjöstedt et al., 2010). Laboratory experiments also point in this direction; that is, it has been demonstrated that increased fluoride pollution increases the mobilisation and leaching of $\mathrm{Al}$ in acid soils (Harrington et al., 2003; Moore and Ritchie, 1988) and that increasing fluoride concentrations below pH 7.5 cause an increase of dissolved Al in water (Wang et al., 2010). Overall, however, the effects of high fluoride levels on Al abundance, speciation and toxicity under natural catchment conditions are not well characterised.

In northern Europe (Norway, Sweden and Finland), stream waters are characterised by overall low pH (Salminen et al., 2005) and an episodic strong decline in pH during the spring flood and other high-flow events (Buffam et al., 2008; Cory et al., 2006; Laudon et al., 2011; Warby et al., 2008). These low pH values mainly results from the widespread occurrence of organic soils and the vulnerable acid-neutralising capacity of the soils and regolith (Laudon et al., 2001). In these streams, therefore, the Al concentrations are typically elevated (Salminen et al., 2005) because of the well-known fact that Al solubility and mobilisation are enhanced under acidic conditions (Gensemer and Playle, 1999). In some areas of northern Europe, streams also have elevated fluoride concentrations in comparison to European streams in general (Salminen et al., 2005). One such area is "the Laxemar area" (located in SE Sweden), where high fluoride concentrations, up to several $\mathrm{mg} / \mathrm{L}$, are caused by the leaching of fluorine-rich bedrock (granites) and regolith (till) (Berger et al., 2012). Accordingly, in addition to the effects from $\mathrm{pH}$, fluoride may also affect both $\mathrm{Al}$ abundance and speciation in streams in this and other similar areas.

The overall aim of the study was to assess the impact of high concentrations of natural dissolved fluoride on $\mathrm{Al}$ concentrations and speciation in stream water. The study was located in the Laxemar area, and included one stream with high fluoride concentrations as a result of the leaching of fluorine-rich geological materials (Berger et al., 2012) and two other previously unstudied streams nearby. Water sampling was carried out during various hydrological conditions, and the Al concentrations were determined from $0.45 \mu \mathrm{m}$ filtered samples. Visual MINTEQ version 3.0 (Gustafsson, 2012) was used to define the Al speciation according to an approach developed by Sjöstedt et al. (2010) and recently applied by Köhler et al. (2014).

\section{Material and Methods}

\subsection{Setting}


The catchment areas of the Kärrsvik (KV) stream (outlet coordinates: $57^{\circ} 26^{\prime} 38^{\prime \prime} \mathrm{N}$; $16^{\circ} 37^{\prime} 26^{\prime \prime} \mathrm{E}$ ), the Ekerum (EK) stream $\left(57^{\circ} 25^{\prime} 8^{\prime \prime} \mathrm{N} ; 1^{\circ} 38^{\prime} 33^{\prime \prime} \mathrm{E}\right)$ and the Laxemar (LX) stream $\left(57^{\circ} 25^{\prime} 4^{\prime \prime} \mathrm{N} ; 1^{\circ} 38^{\prime} 38^{\prime \prime} \mathrm{E}\right)$ are included in this study (Fig. 1). These catchments are generally similar in terms of landscape morphology, with low relief dominated by coniferous and mixed forests (Table 1). These streams are characterised as mesotrophic brown-water systems. Small coastal streams, such as these, play an important role as spawning grounds and feeding areas for many fish species in the Baltic Sea. Six species of fish are found here, according to a survey conducted in LX and EK in 2006: the Ide (Leuciscus idus), Common Roach (Rutilus rutilus), Burbot (Lota lota), Northern Pike (Esox lucius), Eurasian Ruffe (Gymnocephalus cernuus) and Tench (Tinca tinca) (Andersson, 2006; Nordén et al., 2008).

All three catchments are below the highest Holocene coastline and do not reach higher than 63 m.a.s.l. (Table 1). LX has the largest catchment $\left(40.1 \mathrm{~km}^{2}\right)$, followed by $K V\left(27.2 \mathrm{~km}^{2}\right)$ and EK $\left(2.8 \mathrm{~km}^{2}\right)$ (Table 1). The annual mean temperature is $6.4{ }^{\circ} \mathrm{C}$ and the annual precipitation generally reaches a total of 600-700 mm (Werner et al., 2006). These streams have strong seasonal variations in water flow, due to snowmelt during the spring flood and periods of rainfall mainly during the summer and from late autumn to mid-winter. KV and LX are perennial and hold permanent water flows, whereas EK represents an intermittent stream and is usually dry at several locations along its lenght during the summer. The average specific water discharge is $6.1,7.3$ and $5.5 \mathrm{~L} / \mathrm{s} / \mathrm{km}^{2}$ for $\mathrm{KV}, \mathrm{LX}$ and $\mathrm{EK}$, respectively. The annual runoff for the region is estimated to be approximately 150-180 mm (Lindborg, 2005; Werner et al., 2008).

The bedrock of the area is dominated by $1.8 \mathrm{Ga}$ granites and quartz monzodiorites of the Trans-Scandinavian Igneous Belt (TIB) (Wahlgren et al., 2004, 2008). In the northern part of the area, an outcrop of the younger $(1.45 \mathrm{Ga})$ fluorine-enriched Götemar granite pluton occurs (Friese et al., 2012; Kresten and Chyssler, 1976). The region is intersected in several directions by a number of fracture zones. During the Quaternary period, several glaciations influenced the area. The ice sculpted the bedrock surface and removed weathered surface layers. The present surface is thus influenced by mechanical erosion and low-temperature chemical weathering during the Weichselian glaciation and the current inter-glacial period. Exposed bedrock and thin till layers dominate the area; however, the regolith is considerably thicker and often contains glacial clay in the valleys (Sohlenius and Hedenström, 2008). As the coastline regressed due to land uplift, the glacial deposits were partly eroded, resulting in local deposits of sorted materials (Rudmark et al., 2005). Podzols, Leptosols and Regosols are the most common soil types. Wetlands and areas that are used as arable land are to a varying extent underlain by different types of Histosols, that is, soils with a high content of organic matter (Sohlenius and Hedenström, 2008). Other reservoirs of organic matter are the spodic and $\mathrm{O}$ horizons of Podzols and postglacial clays (i.e., gyttja clay).

\subsection{Sampling and analysis}

Stream waters were sampled near the outlet every second to fourth month for approximately 4.5 years at KV (August 2005-December 2009), 4 years at EK (December 2005-December 2009) and 5.5 years at LX (August 2005-December 2010), yielding a total number of 53 stream-water samplings. The water was immediately filtered through $0.45 \mu \mathrm{m}$ 
filters (to exclude particles) and collected in $250 \mathrm{~mL}$ polypropylene bottles for measurements of $\mathrm{pH}$, electrical conductivity (EC), alkalinity, anion concentrations and levels of dissolved organic carbon (DOC), and in $125 \mathrm{~mL}$ acid-washed bottles prepared with $0.8 \%$ Suprapur $^{\mathrm{TM}}$ $\mathrm{HNO}_{3}(65 \%)$ for measurements of cation concentrations. For the measurement of total organic carbon (TOC), unfiltered waters were collected. The $\mathrm{pH}$ values were determined with a potentiometer, the EC with a Conductivity Meter CDM230 and the alkalinity via titration within 24 hours of sampling. Chloride, fluoride and sulfate concentrations were determined by ion chromatography (IC 882, Metrohm). The concentrations of TOC and DOC were determined through combustion catalytic oxidation using a carbon analyser (TOC-5000, Shimadzu). Cations were analysed by ICP-AES/SFMS, and included $\mathrm{Al}, \mathrm{Fe}, \mathrm{Li}, \mathrm{Si}, \mathrm{Na}, \mathrm{K}, \mathrm{Ca}, \mathrm{Mg}$, $\mathrm{Sr}$ and $\mathrm{Mn}$. The median charge balance error was $4.0 \%$. The analytical uncertainties of all the chemical variables are listed in Table 2.

Water-discharge values used in this study were logged hourly from automatic runoff stations close to the outlet of each stream. Information on the installation of the stations and the measurements are presented in Sjögren et al. (2007).

All the analytical and water-discharge data was retrieved from the Site Characterization Database (SICADA), which is owned, quality checked, and supervised by the Swedish Nuclear Fuel and Waste Management Company (SKB), in October-November 2011 and January 2012 (Sicada_11_116, Sicada_11_120_1 and_2). Data for pH, major elements and DOC in KV was previously presented by Berger et al. (2012) and was revisited for this study.

\subsection{Speciation modelling}

The speciation and solubility of Al were modelled using the geochemical model program Visual MINTEQ version 3.0, beta. For inorganic complexes, the thermodynamic default database in this program was used, which is mostly based on the NIST compilation (Smith et al., 2003); for details, see Appendix A. Input data to the model included a wide range of stream-water variables: $\mathrm{pH}$, temperature, $\mathrm{DOC}$, alkalinity (as $\mathrm{HCO}_{3}{ }^{-}$) and the concentrations of $\mathrm{Al}, \mathrm{Ca}, \mathrm{Fe}, \mathrm{K}, \mathrm{Li}, \mathrm{Mn}, \mathrm{Mg}, \mathrm{Na}, \mathrm{Si}, \mathrm{Sr}, \mathrm{Cl}^{-}, \mathrm{F}^{-}$and $\mathrm{SO}_{4}{ }^{2-}$. The water temperature had a mean ( \pm stdev) value of $8.1 \pm 6.0{ }^{\circ} \mathrm{C}$ and ranged from 0 to $20.9{ }^{\circ} \mathrm{C}$. Equilibrium constants were corrected for temperature and ionic strength by use of the van't Hoff and Davies equations, respectively.

Following the approach introduced by Sjöstedt et al. (2010), the Al in filtered samples $\left(\mathrm{Al}_{0.45}\right)$ was allowed to precipitate when the solubility product for $\mathrm{Al}(\mathrm{OH})_{3}(\mathrm{~s})\left(\log { }^{*} K_{\mathrm{s}}\right.$ of 8.29 at $25^{\circ} \mathrm{C}$, see Appendix A) was exceeded. The rationale for choosing this solubility product is that an $\mathrm{Al}(\mathrm{OH})_{3}(\mathrm{~s})$ phase with such a solubility was previously found in the B horizons of Podzols (Gustafsson et al., 1998, 2001), a common soil type in the catchments studied here. The model thus calculates the proportion of the $\mathrm{Al}_{0.45}$ fraction occurring as $\mathrm{Al}(\mathrm{OH})_{3}(\mathrm{~s})$, that is, colloidal Al. Aluminium complexation to dissolved organic matter (DOM) was modelled using the Stockholm Humic Model (SHM). As suggested by Sjöstedt et al. (2010), who studied DOM in 322 lakes included in the Swedish environmental monitoring programme, the DOM consisted of $50 \%$ carbon by weight; $82.5 \%$ of the DOM consisted of active fulvic acid (FA) 
whereas the rest was inactive with respect to proton and metal binding. The abbreviations used for the various modelled Al fractions are given above.

Iron was entered as $\mathrm{Fe}(\mathrm{III})$ and was also allowed to precipitate when exceeding the solubility product of ferrihydrite, having the formula $\mathrm{Fe}(\mathrm{OH})_{3}\left(\log * \mathrm{~K}_{\mathrm{s}}\right.$ of 2.69 at $25^{\circ} \mathrm{C}$, see Appendix $\left.\mathrm{A}\right)$.

\section{Results}

\subsection{Hydrochemistry of the streams}

The $\mathrm{pH}$ was weakly acidic in KV (5.9-6.7) and LX (5.8-7.0) but slightly alkaline in EK (7.0-7.9), and in all three streams the $\mathrm{pH}$ was inversely correlated with water discharge (Fig. 2). The DOC, representing generally $97-98 \%$ of TOC concentration, was high in all three streams (KV 13-35 mg/L, median $22 \mathrm{mg} / \mathrm{L}$; EK 14-22 mg/L, $20 \mathrm{mg} / \mathrm{L}$; LX 13-22 mg/L, $17 \mathrm{mg} / \mathrm{L}$ ) and was uncorrelated with $\mathrm{pH}$ (Fig. 3a) or water flow (Fig. 3b). The fluoride concentrations in KV $(0.65-3.3 \mathrm{mg} / \mathrm{L}$; median 1.1$)$ and EK $(0.83-1.8 \mathrm{mg} / \mathrm{L} ; 1.0)$ were generally twice as high as in LX (0.36-0.81 mg/L; 0.48), and correlated with pH (Fig. 3c) and inversely correlated with water discharge (Fig. $3 \mathrm{~d}$ ) in all three streams. The $\mathrm{Al}$ concentrations $\left(\mathrm{Al}_{0.45}\right)$ decreased in the

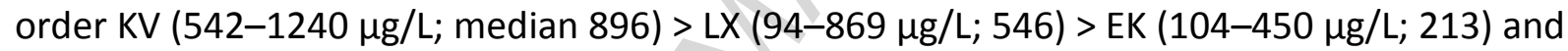
were, in all three streams, inversely correlated with pH (Fig. 4a). The data for other streamwater variables, used in the $\mathrm{Al}$ and fluoride speciation modelling, are presented in Table 2.

\subsection{Model predictions of Al and fluoride speciation}

The ratio of modelled $\mathrm{Al}_{\mathrm{d}}$ to modelled $\mathrm{Al}_{c}$ increased when the measured $\mathrm{Al}$ concentrations $\left(\mathrm{Al}_{0.45}\right)$ increased in response to declining $\mathrm{pH}$ values. Hence, as $\mathrm{pH}$ dropped, the $A l_{d}$ concentrations strongly increased, particularly in KV (Fig. 5a). Overall, the percentage of $\mathrm{Al}_{d}$ (relative to $\left.\mathrm{Al}_{0.45}\right)$ decreased in the order KV (10-100\%; median 52\%) > LX (5-100\%; 37\%) > EK (4-34\%; 18\%).

For the $\mathrm{Al}_{\mathrm{d}}$ pool, organically complexed $\mathrm{Al}\left(\mathrm{Al}_{\mathrm{o}}\right)$ was predicted to dominate. In $\mathrm{KV}$, this $\mathrm{Al}$ fraction accounted for 38-92\% (median 71\%) and was uncorrelated with $\mathrm{pH}$; in $\mathrm{LX}$, the fraction accounted for 68-99\% (median 97\%) and was correlated with $\mathrm{pH}$; and in EK, the fraction accounted for $73-100 \%$ (99\%) and was inversely correlated with $\mathrm{pH}$ (Fig. 6a). In KV, the concentrations of $\mathrm{Al}_{\mathrm{o}}$ were not higher than in $\mathrm{LX}$ (Fig. $5 \mathrm{c}$ ), indicating that other processes are responsible for its elevated $\mathrm{Al}_{\mathrm{d}}$ concentrations at any given $\mathrm{pH}<6.5$ (Fig. 5a). The other part of the $\mathrm{Al}_{d}$ pool, consisting of inorganic monomeric $\mathrm{Al}\left(\mathrm{Al}_{\mathrm{i}}\right)$, clearly showed a pattern that was inverse to the $\mathrm{Al}_{\circ}$ pattern (Fig. 6a). Accordingly, $\mathrm{Al}_{i}$ occurred in the highest proportion in $\mathrm{KV}\left(8.3-62 \%\right.$ of $\mathrm{Al}_{\mathrm{d}}$; median $\left.29 \%\right)$, occasionally in significant but generally low proportions in LX $(0.98-32 \% ; 3.1 \%)$ and in low proportions (with the exception of one data point) in EK (0.49-27\%; 1.4\%). These findings correspond to $\mathrm{Al}_{\mathrm{i}}$ concentrations of $9.4-542 \mathrm{\mu g} / \mathrm{L}$ (median 89.9) in KV, 0.39-201 $\mu \mathrm{g} / \mathrm{L}(4.2)$ in LX and 0.25-2.1 $\mu \mathrm{g} / \mathrm{L}(0.73)$ in EK.

The $\mathrm{Al}_{\mathrm{i}}$ pool was predicted to be strongly dominated by fluoride complexes $\left(\mathrm{Al}_{\mathrm{i}-\mathrm{F}}\right)$ in $\mathrm{KV}(98-$ $100 \%)$, as well as in LX, where there was, however, a greater variation (26-99\%, median 98\%). In EK, the corresponding percentages were $0.1-95 \%$ and a median of $42 \%$. The $\mathrm{Al}_{\mathrm{i}-\mathrm{F}}$ 
species were composed mainly of $\mathrm{AlF}_{2}{ }^{+}$and $\mathrm{AlF}_{3}(\mathrm{aq})$ followed by $\mathrm{AlF}^{2+}$ and $\mathrm{AlF}_{4}$, and were strongly dominating at low $\mathrm{pH}$ (up to 6.7), occurred in percentages equal to or higher than other $\mathrm{Al}_{i}$ phases at a pH of around 7, and were minor at higher $\mathrm{pH}$ values (Fig. 6b). The other $\mathrm{Al}_{i}$ phases were predicted to be mainly $\mathrm{Al}(\mathrm{OH})_{4}{ }^{-}$followed by $\mathrm{Al}(\mathrm{OH})_{3}(\mathrm{aq})$ and $\mathrm{Al}(\mathrm{OH})_{2}{ }^{+}$(in Fig. $6 \mathrm{~b}$ presented as $\mathrm{Al}_{\mathrm{i}-\mathrm{other}}$ ). The $\mathrm{Al}_{\mathrm{i}-\mathrm{F}}$ concentrations were higher, at any given $\mathrm{pH}$, in $\mathrm{KV}$ than in LX (Fig. 5b).

At a pH above 6.3, that is, for all sampling occasions in EK and for a majority of the sampling occasions in KV and LX (Fig. 7), more than $90 \%$ of the dissolved fluoride was predicted to occur as $\mathrm{F}^{-}$(Fig. 7). At lower $\mathrm{pH}$ values, down to 5.8-5.9, dissolved fluoride was predicted to be increasingly complexed with Al (Fig. 7). Hence, a relatively large part of the total fluoride flux is complexed with $\mathrm{Al}$, as during low-pH conditions both the water flow and the fluoride flux is greatest in KV and LX.

\section{Discussion}

\subsection{Concentration levels and main control of Al}

Overall, the concentrations of $\mathrm{Al}_{0.45}$ are controlled by variations in $\mathrm{pH}$ (Fig. 4a), which is a well-known phenomenon (Cory et al., 2006; Haag et al., 2001; Lawrence et al., 1988; Neal, 1995). In two of the studied streams (KV, LX), as in many other catchments elsewhere in the boreal zone, there is an overall decrease in $\mathrm{pH}$ when stream water discharge increases (Fig. 2), caused by consistently high DOC concentrations, but a decrease in acid-neutralising capacity when the groundwater table rises during wet periods (Erlandsson et al., 2010; Laudon and Buffam, 2008; Laudon et al., 2001). Consequently, in these two streams the $\mathrm{Al}_{0.45}$ concentrations reached values up to approximately $1 \mathrm{mg} / \mathrm{L}$ (Fig. 4a), which are relatively high even for boreal streams (Löfgren et al., 2010; Pokrovsky et al., 2006; Salminen et al., 2005). Additionally, as $\mathrm{pH}$ decreases, the modelling suggests that the percentage of $\mathrm{Al}_{\mathrm{d}}$ (relative to $\mathrm{Al}_{0.45}$ ) increases, reaching values up to $100 \%$ on some occasions. Hence, as highflow conditions set in, the KV and LX streams are acidified and loaded with an abundance of dissolved Al. In EK, the pH was generally higher and did not drop below 7.0 even under the highest flow conditions (Fig. 2). In this stream, therefore, there were lower concentrations of $\mathrm{Al}_{0.45}$ (Fig. 4) and a lower percentage of modelled $\mathrm{Al}_{\mathrm{d}}$.

\subsection{Concentration levels and sources of fluoride}

The fluoride concentrations in all streams were high when compared to European and national average values (Salminen et al., 2005), and decreased with distance to the outcropping fluorine-rich granite (Götemar granite), that is, KV (median $1.1 \mathrm{mg} / \mathrm{L}$ ) > EK (1.0 $\mathrm{mg} / \mathrm{L})>\mathrm{LX}(0.48 \mathrm{mg} / \mathrm{L}$ ) (Fig. 1). These results are explained by fluoride leaching from: (i) the granite, which includes fluorine in primary minerals such as biotite, muscovite and fluorite (Kornfält et al., 1997; Kresten and Chyssler, 1976) and secondary minerals such as fluorite, topaz and muscovite in veins and greisen (Alm et al., 2005; Drake and Tullborg, 2009a; Drake et al., 2009b; Kresten and Chyssler, 1976); and (ii) the regolith around the granite, formed during the last Pleistocene glaciation and consisting of bedrock debris. The decrease in fluoride concentrations when pH decreased (Fig. 3c) and water discharge increased (Fig. 3d) 
is thus mainly explained through the source dependence, that is, dilution by surface water runoff.

\subsection{Impact of fluoride on Al in stream water}

For a given $\mathrm{pH}$ value, the concentrations of both measured $\mathrm{Al}\left(\mathrm{Al}_{0.45}\right)$ and modelled dissolved $\mathrm{Al}\left(\mathrm{Al}_{\mathrm{d}}\right)$ were generally considerably higher in KV than in LX (Fig. 4a, Fig. 5a). This result shows that there is an additional important factor, apart from $\mathrm{pH}$, causing a rise in $\mathrm{Al}$ concentrations in KV. The major differences between KV and LX are that in the former there were: (i) much higher concentrations of fluoride (Table 2), a ligand that forms strong complexes with Al (LaZerte et al., 1997); and (ii) no inverse correlation between $\mathrm{Al}_{0.45}$ and fluoride (Fig. 4b). In line with these features, the model predicts that in $\mathrm{KV}$ the $\mathrm{Al}_{\mathrm{i}-\mathrm{F}}$ complex occurs, at any given $\mathrm{pH}$, both in higher concentrations (Fig $5 \mathrm{~b}$ ) and higher proportions (Fig. 6a) than in LX. Taken together, these analytical and modelling results indicate that the high fluoride levels in $\mathrm{KV}$ increase the extent to which $\mathrm{Al}$ is complexed with fluoride, which in turn increases both the ratio of inorganically to organically complexed $\mathrm{Al}_{\mathrm{d}}$ and the concentrations of $\mathrm{Al}_{\mathrm{d}}$ and $\mathrm{Al}_{0.45}$ in stream water. In contrast, the model prediction that $\mathrm{KV}$ does not have elevated concentrations of organically complexed Al (Fig. 5c) suggests that dissolved organic substances have not contributed to raise the Al concentrations in this stream above those in LX. The interaction between fluoride and Al may occur already in the water in the source materials (bedrock fractures and regolith, including the soil), enhancing Al mobilisation and leaching and ultimately resulting in the characteristic Al features detected in KV. This surmise is supported by previous studies showing that Al concentrations in soil (Ultisols) solutions are related to fluoride sorption, suggesting fluoride-assisted dissolution of Albearing amorphous and crystalline soil minerals (Harrington et al., 2003).

For LX, which had the lowest fluoride concentrations (Table 2), the model predicted that $A l_{d}$ was increasingly complexed with fluoride as $\mathrm{pH}$ declined, with values up to approximately $25 \%$ for the lowest $\mathrm{pH}$ (Fig. 6a). This trend is counter-intuitive, because with declining pH there is a decrease in fluoride concentrations (Fig. 3c). These features are, however, reasonable and can be explained by the fact that at declining $\mathrm{pH}$, organic substances (the main ligand competitor with fluoride) are successively protonated, minimising their efficiency as a ligand and allowing fluoride complexation to expand. In LX, therefore, the influence of fluoride on $\mathrm{Al}$ is most distinguished during low $\mathrm{pH}$ conditions. In EK, which had equally high fluoride concentrations as KV (Table 2) but consistently high pH (Fig. 2), the $\mathrm{Al}_{0.45}$ concentrations were generally low (Fig. 4a) and, according to the model, the $\mathrm{Al}_{\mathrm{d}}$ pool was strongly dominated by $\mathrm{Al}_{\mathrm{o}}$ (Fig. 6a). Hence, at high-pH conditions, which prevail throughout in EK, fluoride seems not to form complexes with $\mathrm{Al}$, and thus has only a marginal impact on it.

\subsection{Toxicological implications}

We have shown that in KV, a fluoride-rich and episodically acidic stream, the concentrations of $\mathrm{Al}_{\mathrm{i}}$ are enhanced as a result of fluoride complexation. This enhancement may have effects on the aquatic ecology, because several fish species in boreal waters are sensitive to acidity and/or to dissolved inorganic Al (Andrén and Rydin, 2012; Appelberg et al., 1992; Grassie et 
al., 2013; Poleo and Muniz, 1993; Poleo et al., 1997). Considering thresholds set by the Swedish Environmental Protection Agency, SEPA $(2002 ; 2010)$, in KV the modelled $\mathrm{Al}_{\mathrm{i}}$ was above the level for "effects on sensitive species" $(30-50 \mu \mathrm{g} / \mathrm{L})$ in $76 \%$ of the samples, and above the level for "effects on tolerant species" (>50 $\mathrm{\mu g} / \mathrm{L}$ ) in $70 \%$ of the samples. Yet, because $\mathrm{Al}_{\mathrm{i}}$ in this stream was modelled to be composed exclusively of $\mathrm{Al}_{\mathrm{i}-\mathrm{F}}$ (Fig. 6b), the precise biological effect of the high levels of modelled $\mathrm{Al}_{\mathrm{i}}$ is not known with certainty. However, Stevens et al. (1997) have shown that $\mathrm{Al}_{\mathrm{i}-\mathrm{F}}$ increases phytotoxicity in oats (Avena sativa) and tomatoes (Lycopersicon esculentum), and according to Strunecká and Patocka (2002), the synergistic action of $\mathrm{Al}_{\mathrm{i}-\mathrm{F}}$ in water and in the food chain causes various diseases affecting metabolism, growing processes and homeostasis in living organisms. Exley (2000) has shown that avoidance behaviour (as well as mortality) in fish (and other organisms) increases in acidic waters when $\mathrm{Al}$ increases. It is thus possible that avoidance behaviour in aquatic organisms might be amplified when $\mathrm{Al}_{d}$ is increased and the $\mathrm{Al}_{i}$ pool is composed of $\mathrm{Al}_{\mathrm{i}-\mathrm{F}}$, as a result of significant quantities of dissolved fluoride in acidic systems.

\section{Conclusions}

The major conclusions are:

- When $\mathrm{pH}$ declined, the fluoride concentrations decreased, and both the measured $\mathrm{Al}$ $\left(\mathrm{Al}_{0.45}\right)$ and modelled dissolved $\mathrm{Al}\left(\mathrm{Al}_{\mathrm{d}}\right)$ concentrations increased. Despite these features, the model predicts that with declining $\mathrm{pH}$, the proportion of Al complexed with fluoride (relative to Al complexed with organic substances) is either maintained (KV) or even increased (LX). This prediction indicates that fluoride as a complexing agent for $\mathrm{Al}$ is particularly important at low $\mathrm{pH}$ values, and that in these two streams the fluoride concentrations at low $\mathrm{pH}$ are high enough to bind a substantial amount of Al. In contrast, in the third studied stream (EK), which was not episodically acidic, Al binding to fluoride was predicted to be low despite high fluoride concentrations.

- For the two studied streams that experience episodic declines in $\mathrm{pH}$, both the $\mathrm{Al}_{0.45}$ and $\mathrm{Al}_{d}$ concentrations were higher in the stream with high fluoride concentrations (KV) than in the one with lower fluoride concentrations (LX). Both the analytical data and modelling results point to fluoride as the main reason for the elevated Al concentrations in $\mathrm{KV}$.

- The modelling indicates that in the fluoride-rich episodically acidic stream (KV), inorganic monomeric Al was bound exclusively with fluoride and frequently occurred in levels stated as harmful to fish. This finding highlights the importance of reaching consensus regarding the ambiguous toxicological nature of the part of inorganic monomeric Al that is complexed with fluoride.

\section{Acknowledgements}

Analytical and water-discharge data for this study was kindly supplied by the Swedish Nuclear Fuel and Waste Management Company (SKB). The support from Nova FoU (research and development) in Oskarshamn, Sweden, is greatly appreciated.

\section{References}


All SKB (Swedish Nuclear Fuel and Waste Management Company) scientific reports can be downloaded at www.skb.se.

Alm, E., Sundblad, K., Huhma, H., 2005. Sm-Nd isotope determinations of low-temperature fluorite-calcite-galena mineralization in the margins of the Fennoscandian Shield. Swedish Nuclear Fuel and Waste Management Co. (SKB). Report R-05-66, Stockholm, Sweden.

Andersson, R., 2006. Electrofishing in two streams in the Simpevarp area. A study of movement of migratory fish species. Oskarshamn Site Investigation. Swedish Nuclear Fuel and Waste Management Co. (SKB). Report P-06-251., Stockholm, Sweden.

Andrén, C.M., Rydin, E., 2012. Toxicity of inorganic aluminium at spring snowmelt-in-stream bioassays with brown trout (Salmo trutta L.). Sci. of the Total Environ., 437: 422-432.

Appelberg, M., Degerman, E., Norrgren, L., 1992. Effects of acidification and liming on fish in Sweden: A review. Finnish Fisheries Res., 13(0): 77-91.

Berger, T., Peltola, P., Drake, H., Åström, M., 2012. Impact of a fluorine-rich granite intrusion on levels and distribution of fluoride in a small boreal catchment. Aquatic Geochem., 18(2): 77-94.

Bi, S.P., 2001. Speciation of aluminum in the stream waters from the Susquehanna River watershed, Chesapeake Bay. Environmental Geology, 40(3): 300-304.

Brunberg, A.-K., Carlsson, T., Brydsten, L., Strömgren, M., 2004. Identification of catchments, lake-related drainage parameters and lake habitats. Oskarshamn Site Investigation. Swedish Nuclear Fuel and Waste Management Co. (SKB). Report P-04-242., Stockholm, Sweden.

Buffam, I., Laudon, H., Seibert, J., Mörth, C.M., Bishop, K., 2008. Spatial heterogeneity of the spring flood acid pulse in a boreal stream network. Sci. of the Total Environ., 407(1): 708-722.

Cory, N., Buffam, I., Laudon, H., Köhler, S., Bishop, K., 2006. Landscape control of stream water aluminum in a boreal catchment during spring flood. Environmental Sci. \& Technol., 40(11): 3494-3500.

Deng, Y., Nordstrom, D.K., Blaine McCleskey, R., 2011. Fluoride geochemistry of thermal waters in Yellowstone National Park: I. Aqueous fluoride speciation. Geochimica et Cosmochimica Acta, 75(16): 4476-4489.

Drake, H., Tullborg, E.-L., 2009a. Paleohydrogeological events recorded by stable isotopes, fluid inclusions and trace elements in fracture minerals in crystalline rock, Simpevarp area, SE Sweden. Appl. Geochem., 24(4): 715-732. 
Drake, H., Tullborg, E.-L., Page, L., 2009b. Distinguished multiple events of fracture mineralisation related to far-field orogenic effects in Paleoproterozoic crystalline rocks, Simpevarp area, SE Sweden. Lithos, 110(1-4): 37-49.

Erlandsson, M., Laudon, H., Folster, J., 2010. Spatiotemporal patterns of drivers of episodic acidification in Swedish streams and their relationships to hydrometeorological factors. Sci. of the Total Environ., 408(20): 4633-4643.

Exley, C., 2000. Avoidance of aluminum by rainbow trout. Environmental Toxicol. and Chem., 19(4): 933-939.

Frankowski, M., Ziola-Frankowska, A., 2010. Speciation analysis of aluminium and aluminium fluoride complexes by HPIC-UVVIS. Talanta, 82(5): 1763-1769.

Friese, N., Vollbrecht, A., Tanner, D.C., Fahlbusch, W., Weidemann, M., 2012. Multi-stage emplacement of the Götemar Pluton, SE Sweden: New evidence inferred from field observations and microfabric analysis, including cathodoluminescence microscopy. International J. of Earth Sci., 101(5): 1149-1167.

Gensemer, R.W., Playle, R.C., 1999. The bioavailability and toxicity of aluminum in aquatic environments. Crit. Rev. in Environmental Sci. and Technol., 29(4): 315-450.

Grassie, C. et al., 2013. Aluminum exposure impacts brain plasticity and behaviour in Atlantic salmon (Salmo salar). J. of Experimental Biol., 216(16): 3148-3155.

Gustafsson, J.P., 2012. Visual MINTEQ version 3.0. http://www2.Iwr.kth.se/English/Oursoftware/vminteq/ (accessed February, 2012)

Gustafsson, J.P., Berggren, D., Simonsson, M., Zysset, M., Mulder, J., 2001. Aluminium solubility mechanisms in moderately acid Bs horizons of podzolized soils. Eur. J. of Soil Sci., 52(4): 655-665.

Gustafsson, J.P., Lumsdon, D.G., Simonsson, M., 1998. Aluminium solubility characteristics of spodic B horizons containing imogolite-type materials. Clay Miner., 33(1): 77-86.

Haag, I., Moritz, K., Bittersohl, J., Lischeid, G., 2001. Factors controlling total concentration and aqueous speciation of aluminium in an acidic headwater stream of the Bavarian Forest National Park: A modelling approach. Acta Hydrochimica et Hydrobiologica, 29(4): 206-218.

Harrington, L.F., Cooper, E.M., Vasudevan, D., 2003. Fluoride sorption and associated aluminum release in variable charge soils. J. of Colloid and Interface Sci., 267(2): 302313.

Kornfält, K.-A., Persson, P.-O., Wikman, H., 1997. Granitoids from the Äspö area, southeastern Sweden-Geochemical and geochronological data. GFF, 119(2): 109114. 
Kresten, P., Chyssler, J., 1976. The Götemar Massif in south-eastern Sweden: A reconnaissance survey. Geol. Fören. i Stockh. Förhandlingar [Geol. Soc. in Stockh. Negotiat.], 98: 155-161.

Köhler, S.J., Lidman, F., Laudon, H., 2014. Landscape types and pH control organic matter mediated mobilization of Al, Fe, $\mathrm{U}$ and $\mathrm{La}$ in boreal catchments. Geochimica et Cosmochimica Acta, 135: 190-202.

Laudon, H. et al., 2011. Patterns and dynamics of dissolved organic carbon (DOC) in boreal streams: The role of processes, connectivity, and scaling. Ecosyst., 14(6): 880-893.

Laudon, H., Buffam, I., 2008. Impact of changing DOC concentrations on the potential distribution of acid sensitive biota in a boreal stream network. Hydrology and Earth Syst. Sci., 12(2): 425-435.

Laudon, H., Westling, O., Löfgren, S., Bishop, K., 2001. Modelling preindustrial ANC and pH during the spring flood in northern Sweden. Biogeochem., 54(2): 171-195.

Lawrence, G.B., Driscoll, C.T., Fuller, R.D., 1988. Hydrologic control of aluminium chemistry in an acidic headwater stream. Water Resour. Res., 24(5): 659-669.

LaZerte, B. D., van Loon, G., Anderson, B., 1997. Aluminum in water, In: Research Issues in Aluminum Toxicity, pp. 17-45. (Yokel, R. A. and Golub, M. S., Ed.) Washington, DC, Taylor and Francis.

Lindborg, T., 2005. Description of surface systems. Preliminary site description. Simpevarp sub area-Version 1.2. Swedish Nuclear Fuel and Waste Management Co. (SKB). Report R-05-01. SKB R-05-01, Stockholm, Sweden.

Löfgren, S., Cory, N., Zetterberg, T., 2010. Aluminium concentrations in Swedish forest streams and co-variations with catchment characteristics. Environmental Monit. and Assess., 166(1): 609-624.

Moore, C.S., Ritchie, G.S.P., 1988. Aluminium speciation and $\mathrm{pH}$ of an acid soil in the presence of fluoride. J. of Soil Sci., 39(1): 1-8.

Neal, C., 1995. Aluminium speciation variations in an acidic upland stream draining the Hafren spruce forest, Plynlimon, Mid-Wales. J. of Hydrology, 164(1-4): 39-51.

Nordén, S., Söderbäck, B., Andersson, E., 2008. The limnic ecosystems at Forsmark and Laxemar-Simpevarp. Site Descriptive Modeling, SDM-Site. Swedish Nuclear Fuel and Waste Management Co. (SKB). Report R-08-02, Stockholm, Sweden.

Pokrovsky, O.S., Schott, J., Dupre, B., 2006. Trace element fractionation and transport in boreal rivers and soil porewaters of permafrost-dominated basaltic terrain in Central Siberia. Geochimica et Cosmochimica Acta, 70(13): 3239-3260. 
Poleo, A.B.S., Muniz, I.P., 1993. The effect of aluminum on soft-water at low $\mathrm{pH}$ and different temperatures on mortality, ventialtion frequency and water-balance in smoltifying Atlantic salmon, Salmo salar. Environmental Biol. of Fishes, 36(2): 193-203.

Poleo, A.B.S. et al., 1997. Toxicity of acid aluminium-rich water to seven freshwater fish species: A comparative laboratory study. Environmental Pollut., 96(2): 129-139.

Rudmark, L., Malmberg-Persson, K., Mikko, H., 2005. Investigation of Quaternary deposits 2003-2004. Oskarshamn Site Investigation. Swedish Nuclear Fuel and Waste Management Co. (SKB). Report P-05-49. Stockholm, Sweden. SKB P-05-49.

Salminen, R. et al., 2005. Geochemical Atlas of Europe. Part 1-Background Information, Methodology and Maps. Geological Surv. of Finl., Espoo.

SEPA, 2002. Kalkning av sjöar och vattendrag [Liming of lakes and streams]. Handbok 2002:1, SEPA (Swedish Environmental Protection Agency), Stockholm.

SEPA, 2010. Kalkning av sjöar och vattendrag [Liming of lakes and streams]. Handbok 2010:2, SEPA (Swedish Environmental Protection Agency), Stockholm.

Sjögren, J., Hillgren, R., Wern, L., Jones, J., Engdahl, A., 2007. Hydrological and meteorological monitoring at Oskarshamn, July 2005 until December 2006. Swedish Nuclear Fuel and Waste Management Co. (SKB). Report R-07-38, Stockholm, Sweden.

Sjöstedt, C.S., Gustafsson, J.P., Köhler, S.J., 2010. Chemical equilibrium modeling of organic acids, $\mathrm{pH}$, aluminum, and iron in Swedish surface waters. Environmental Sci. \& Technol., 44(22): 8587-8593.

Smith, R.M., Martell, A.E., Motekanis, R.J., 2003. NIST critically selected stability constants of metal complexes. NIST Standard Reference Database 46, Version 7.0, Gaithersburg, MD, USA.

Sohlenius, G., Hedenström, A., 2008. Description of regolith at Laxemar-Simpevarp. Site Descriptive Modelling SDM-Site Laxemar. Swedish Nuclear Fuel and Waste Management Co. (SKB). Report R-08-05. Stockholm, Sweden.

Stevens, D.P., McLaughlin, M.J., Alston, A.M., 1997. Phytotoxicity of aluminium-fluoride complexes and their uptake from solution culture by Avena sativa and Lycopersicon esculentum. Plant and Soil, 192(1): 81-93.

Strunecká, A., Patocka, J., 2002. Aluminofluoride complexes: A useful tool in laboratory investigations, but a hidden danger for living organisms? In: Shapiro, P.J., Atwood, D.A. (Eds.), Group 13 Chemistry: From Fundamentals to Applications. Acs Symposium Series, pp. 271-282. 
Wahlgren, C.-H. et al., 2008. Geology Laxemar. Site Descriptive Modelling, SDM-Site Laxemar. Swedish Nuclear Fuel and Waste Management Co. (SKB). Report R-08-54. R08-54, Stockholm, Sweden.

Wahlgren, C.-H. et al., 2004. Bedrock mapping 2003-Simpevarp subarea. Outcrop data, fracture data, modal and geochemical classification of rock types, bedrock map, radiometric dating. Oskarshamn Site Investigation. Swedish Nuclear Fuel and Waste Management Co. (SKB). Report P-04-102. P-04-102, Stockholm, Sweden.

Wang, W.D., Yang, H.W., Wang, X.C., Jiang, J., Zhu, W.P., 2010. Factors affecting aluminum speciation in drinking water by laboratory research. J. of Environmental Sci.-China, 22(1): 47-55.

Warby, R.A.F., Johnson, C.E., Driscoll, C.T., 2008. Changes in aluminum concentrations and speciation in lakes across the northeastern US following reductions in acidic deposition. Environmental Sci. \& Technol., 42(23): 8668-8674.

Werner, K., Bosson, E., Berglund, S., 2006. Description of climate, surface hydrology, and near-surface hydrogeology. Preliminary Site Description, Laxemar Subarea-Version 1.2. Swedish Nuclear Fuel and Waste Management Co. (SKB). Report R-05-61. SKB R05-61 Stockholm, Sweden.

Werner, K., Öhman, J., Holgersson, B., Rönnback, K., Marelius, F., 2008. Metereological, hydrological and hydrogeological monitoring data and near-surface hydrogeological properties data from Laxemar-Simpevarp. Site Descriptive Modelling, SDM-Site Laxemar. Swedish Nuclear Fuel and Waste Management Co. (SKB). Report R-08-73, Stockholm, Sweden. 


\section{Figure captions}

Fig. 1. Overview of the study area. Symbols indicate sampling points at stream outlets of Kärrsvik (KV; open circle), Ekerum (EK; cross) and Laxemar (LX; filled circle).

Fig. 2. pH vs. specific water discharge in the three investigated streams.

Fig. 3. Concentrations of dissolved organic carbon (DOC) vs. $\mathrm{pH}(\mathrm{a})$ and specific discharge (b) and $\mathrm{F}^{-}$vs. $\mathrm{pH}(\mathrm{c})$ and specific discharge (d) in the three investigated streams.

Fig. 4. Concentrations of $A l$ in filtered $(0.45 \mu \mathrm{m})$ samples $\left(\mathrm{Al}_{0.45}\right)$ vs. (a) $\mathrm{pH}$, (b) $\mathrm{F}^{-}$and (c) $\mathrm{DOC}$ in the three investigated streams.

Fig. 5. Modelled concentrations of dissolved $A l\left(A l_{d}, a\right)$, fluoride-complexed $A l\left(A l_{i-F}, b\right)$ and organically complexed $\mathrm{Al}\left(\mathrm{Al}_{\mathrm{O}}, \mathrm{C}\right)$ as a function of $\mathrm{pH}$ in the three investigated streams.

Fig. 6. Percentages of modelled Al fractions versus $\mathrm{pH}$. Upper panel (a) presents the percentages of inorganic monomeric $\mathrm{Al}\left(\mathrm{Al}_{\mathrm{i}}\right)$ and organically complexed $\mathrm{Al}\left(\mathrm{Al}_{\mathrm{o}}\right)$ relative to the pool of dissolved $A I\left(A I_{d}\right)$, whereas the lower panel (b) presents the speciation of $A l$ for inorganic monomeric $\mathrm{Al}\left(\mathrm{Al}_{\mathrm{i}-\mathrm{other}}\right.$ refers to inorganic $\mathrm{Al}$ except $\left.\mathrm{Al}_{\mathrm{i}-\mathrm{F}}\right)$.

Fig. 7. Modelled fluoride speciation as a function of $\mathrm{pH}$ in the three studied streams. $\mathrm{F}_{\text {other }}$ refers to complexes (in the order of modelled concentration) $\mathrm{MgF}^{+}, \mathrm{CaF}^{+}, \mathrm{NaF}(\mathrm{aq}$ ) and $\mathrm{HF}$ (aq). 
Figure 1

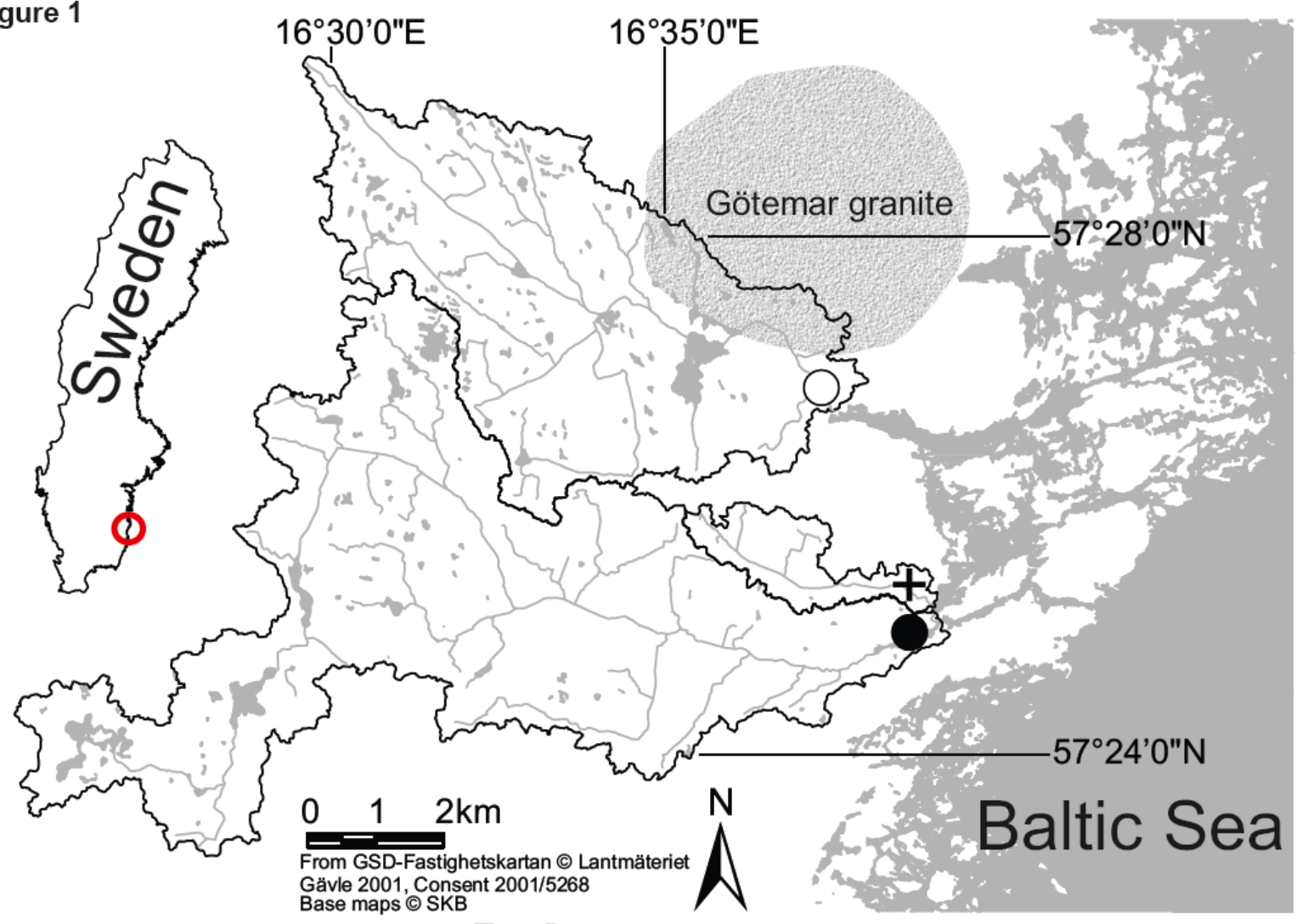


Figure 2

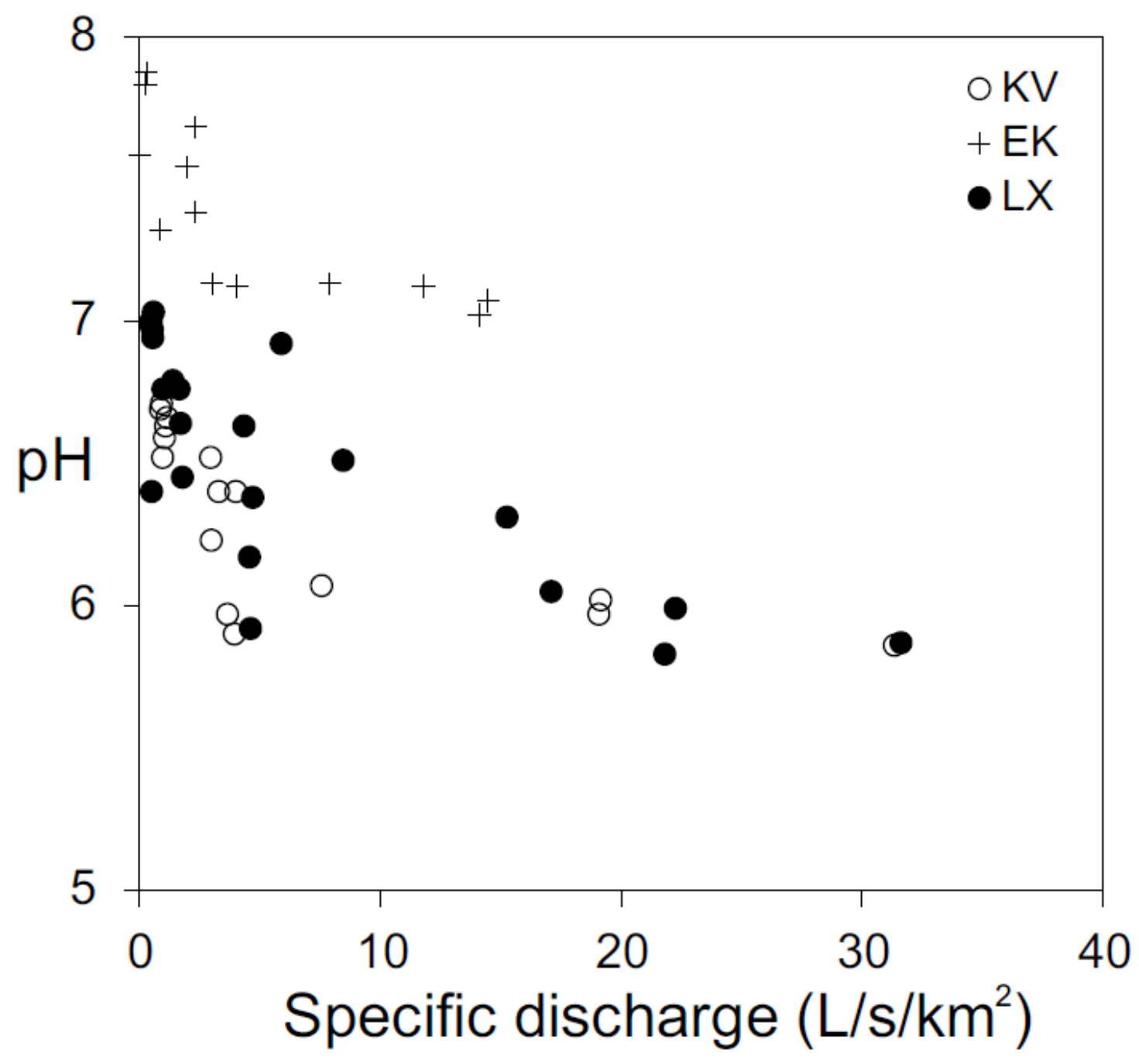


Figure 3

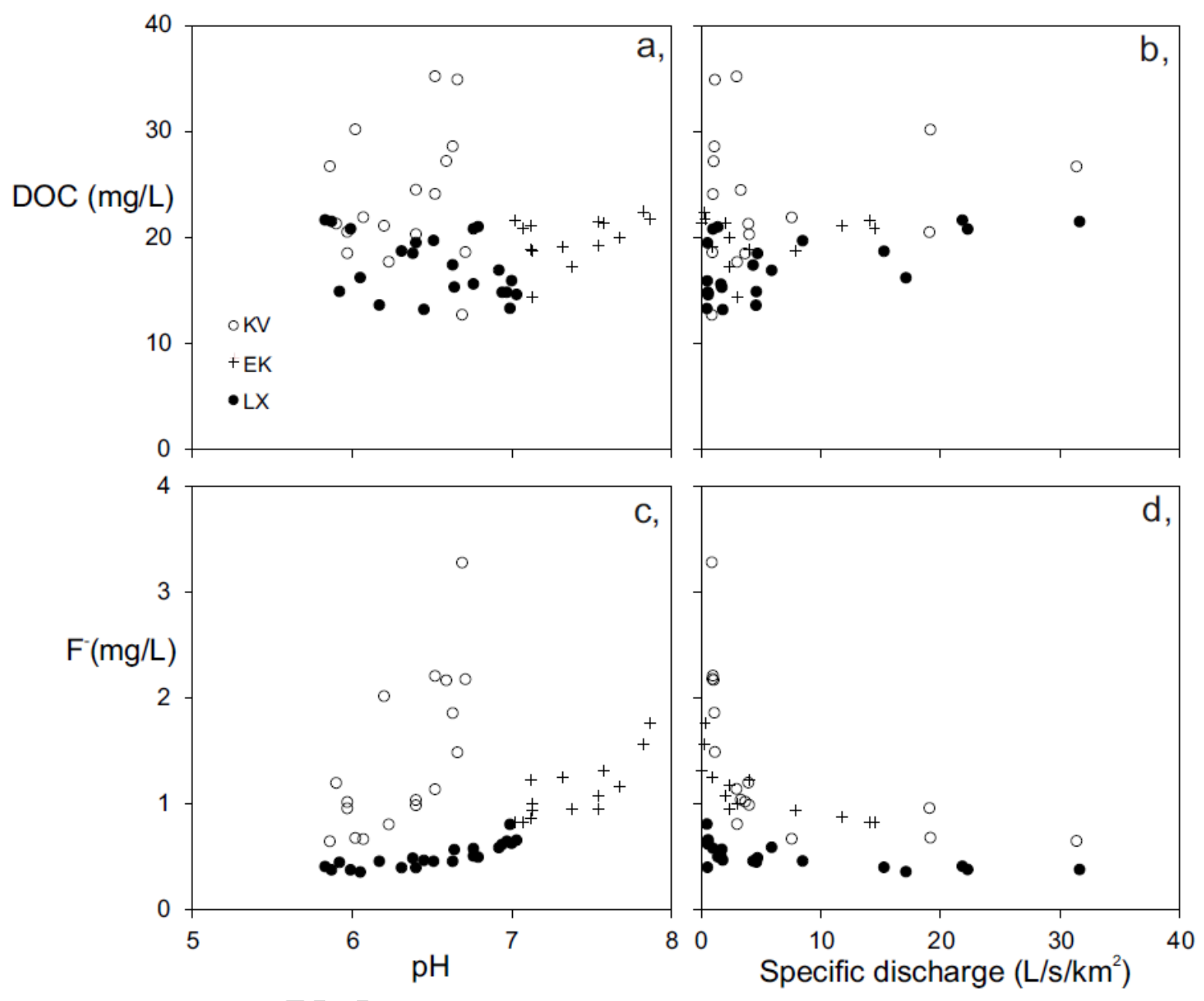


Figure 4

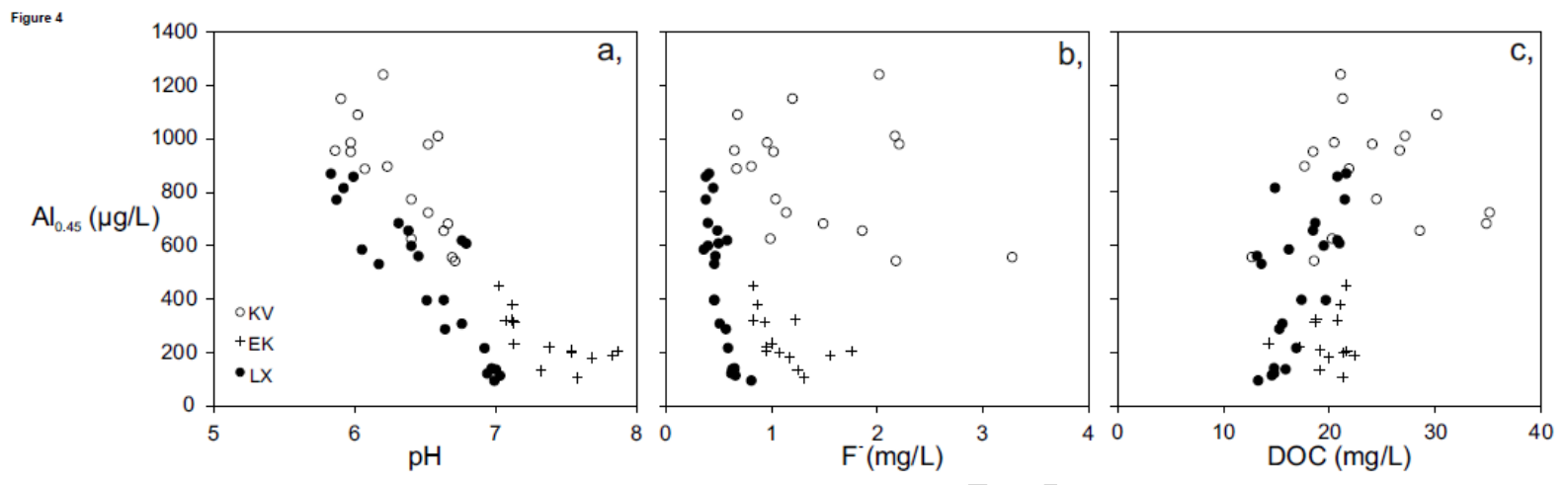


Figure 5
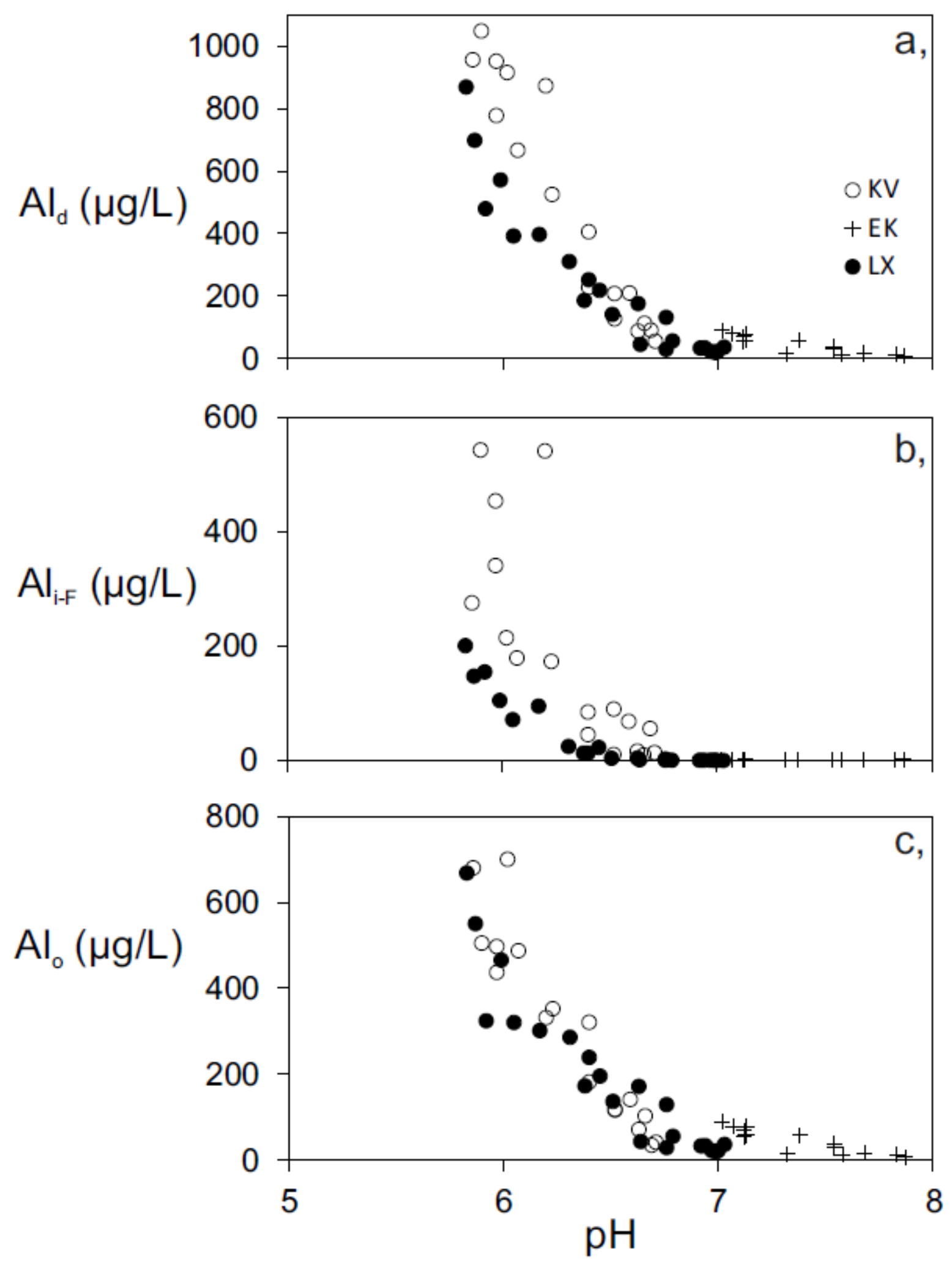
Figure 6
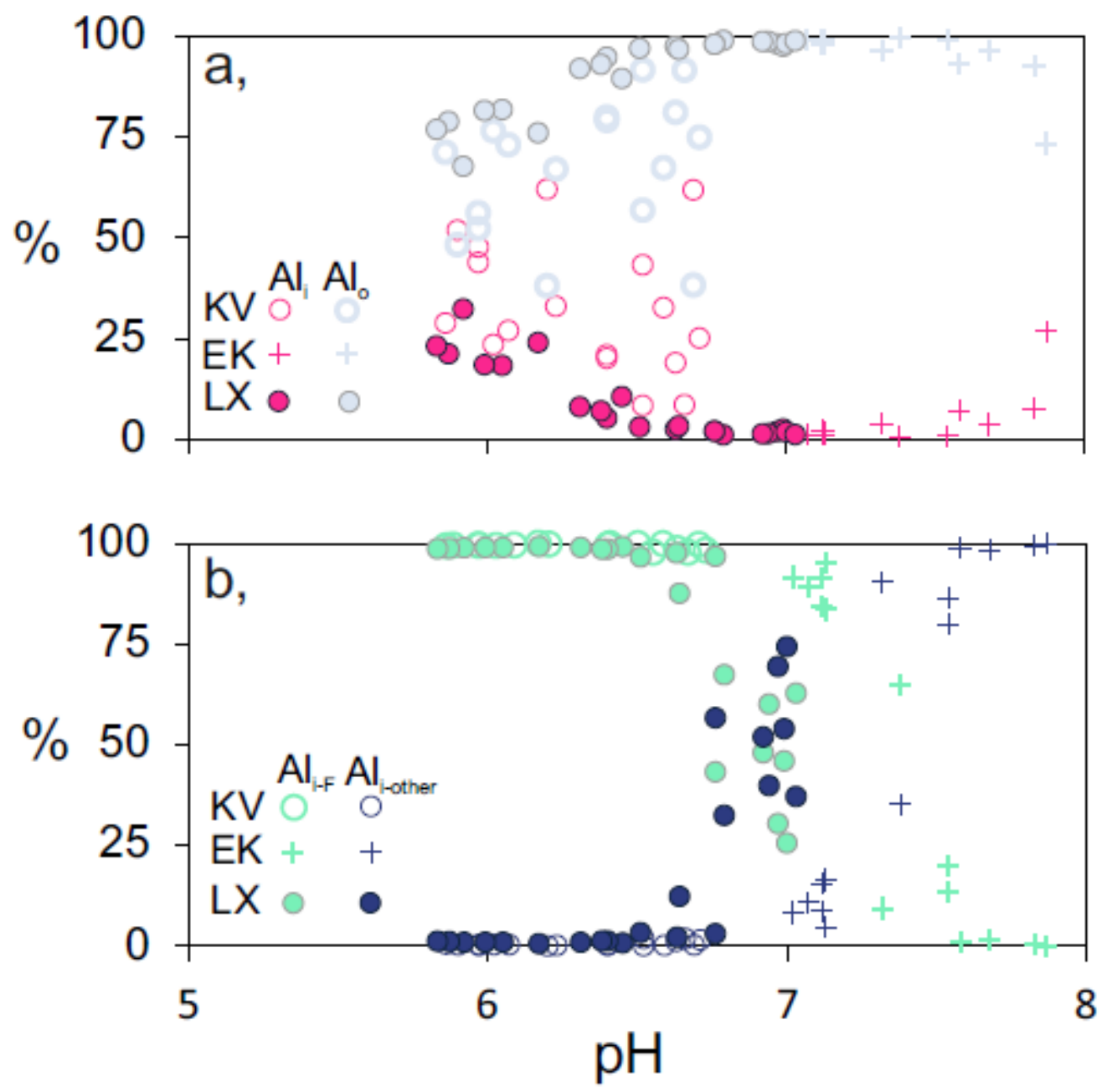
Figure 7

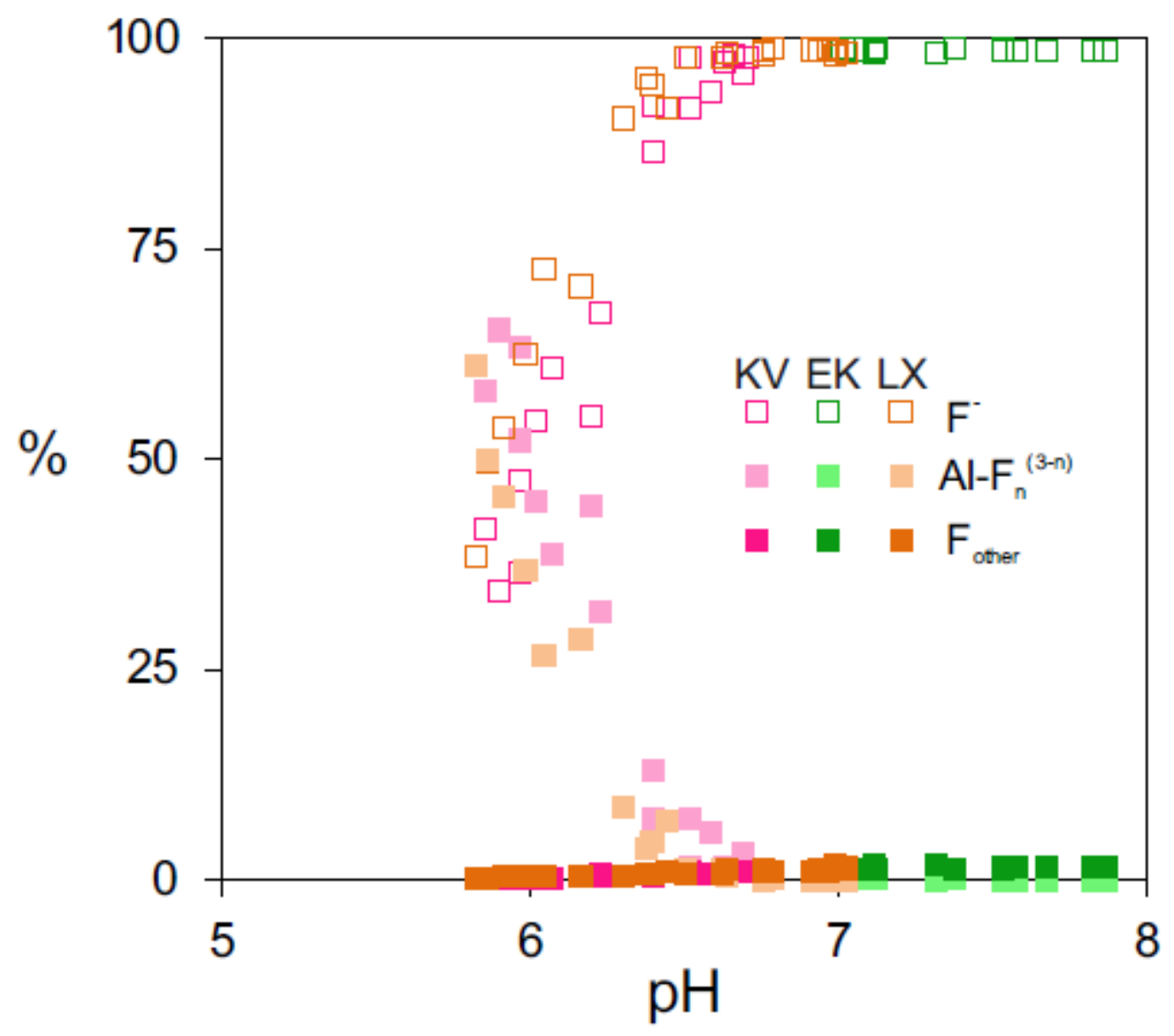


Table 1

Selected features of the catchments.

\begin{tabular}{lccc}
\hline & Kärrsvik (KV) & Ekerum (EK) & Laxemar (LX) \\
\hline${\text { Area }\left(\mathrm{km}^{2}\right)^{1}}_{\mathrm{M} \mathrm{a} \mathrm{s} \mathrm{I} \mathrm{(min-max)}}{ }^{1}$ & 27.2 & 2.8 & 40.1 \\
& $2-50$ & $1-31$ & $1-63$ \\
\hline Land use $^{1}$ & & & \\
\hline Coniferous- and mixed forest $^{2}$ & 88 & 84 & 86 \\
Decidous forest & 1 & 0 & 1 \\
Water surface $_{\text {Wetland }}$ & 0 & 0 & 1 \\
Agriculture land $_{\text {Remaining open land }}$ & 4 & 0 & 2 \\
\hline${ }^{1}$ & 4 & 12 & 5 \\
\hline
\end{tabular}

${ }^{1}$ From Brunberg et al. (2004)

${ }^{2}$ Including cut forest

${ }^{3}$ Including wetlands in both forest and open land 


\section{Table 2}

Median (min-max) values of temperature and the chemical variables included in the study.

\begin{tabular}{|c|c|c|c|c|c|}
\hline \multirow[t]{2}{*}{ Parameter } & \multirow{2}{*}{$\begin{array}{c}\text { LOD } \\
\text { or interval }\end{array}$} & \multirow{2}{*}{$\begin{array}{c}\text { Analytical } \\
\text { uncertainty* }\end{array}$} & Kärrsvik (KV) & \multirow{2}{*}{$\begin{array}{l}\text { Ekerum (EK) } \\
14\end{array}$} & \multirow{2}{*}{$\begin{array}{l}\text { Laxemar (LX) } \\
22\end{array}$} \\
\hline & & & 17 & & \\
\hline $\mathrm{pH}$ (pH units) & $3-10$ & \pm 0.1 & $6.4(5.9-6.7)$ & $7.4(7.0-7.9)$ & $6.6(5.8-7.0)$ \\
\hline $\mathrm{T}\left({ }^{\circ} \mathrm{C}\right)$ & - & - & $5.2(0.1-16.8)$ & $4.6(0-18.3)$ & $6.6(0-20.9)$ \\
\hline $\mathrm{Al}_{0,45}(\mu \mathrm{g} / \mathrm{L})$ & 0.2 & $18 \%$ & $896(542-1240)$ & $213(104-450)$ & $546(94-869)$ \\
\hline $\mathrm{F}^{-}(\mathrm{mg} / \mathrm{L})$ & 0.1 & $12 \%$ & $1.1(0.65-3.3)$ & $1.0(0.83-1.8)$ & $0.48(0.36-0.81)$ \\
\hline $\mathrm{DOC}(\mathrm{mg} / \mathrm{L})$ & 0.5 & $8 \%$ & $22(13-35)$ & $20(14-22)$ & $17(13-22)$ \\
\hline $\mathrm{Fe}(\mathrm{mg} / \mathrm{L})$ & 0.02 & $13 \%$ & $1.7(0.54-4.5)$ & $0.64(0.30-2.7)$ & $0.94(0.49-3.4)$ \\
\hline $\mathrm{Na}(\mathrm{mg} / \mathrm{L})$ & 0.1 & $13 \%$ & $8.8(5.3-21)$ & $16(8.0-25)$ & $13(7.2-40)$ \\
\hline $\mathrm{K}(\mathrm{mg} / \mathrm{L})$ & 0.4 & $12 \%$ & $1.4(0.92-2.9)$ & $1.3(0.94-2.4)$ & $1.8(1.2-4.1)$ \\
\hline $\mathrm{Ca}(\mathrm{mg} / \mathrm{L})$ & 0.1 & $12 \%$ & $14(8.0-19)$ & $36(30-53)$ & $14(9.0-26)$ \\
\hline $\mathrm{Mg}(\mathrm{mg} / \mathrm{L})$ & 0.09 & $12 \%$ & $3.2(1.7-4.2)$ & $4.9(3.9-7)$ & $3.6(2.5-6.4)$ \\
\hline Alkalinity $\left(\right.$ as $\left.\mathrm{HCO}_{3}{ }^{-}\right)(\mathrm{mg} / \mathrm{L})$ & 1.0 & $4 \%$ & $15(5.0-36)$ & $75(36-93)$ & $15(3.6-46)$ \\
\hline $\mathrm{Cl}^{-}(\mathrm{mg} / \mathrm{L})$ & 0.5 & $8 \%$ & $12(6.5-25)$ & $21(14-27)$ & $20(11-59)$ \\
\hline $\mathrm{SO}_{4}{ }^{2-}(\mathrm{mg} / \mathrm{L})$ & 0.5 & $12 \%$ & $20(12-45)$ & $42(21-113)$ & $23(13-59)$ \\
\hline Si (mg/L) & 0.03 & $14 \%$ & $10(8.6-14)$ & $12(8.4-15)$ & $9.6(6.4-13)$ \\
\hline $\mathrm{Mn}(\mathrm{mg} / \mathrm{L})$ & 0.003 & $12 \%$ & $0.07(0.03-0.14)$ & $0.06(0.005-0.15)$ & $0.07(0.02-0.16)$ \\
\hline
\end{tabular}

${ }^{*}$ Calculated at the $95 \%$ confidence level

LOD = Limit of detection 


\section{Highlights}

- High fluoride levels contribute to raise $\mathrm{Al}$ abundance and the ratio of inorganic to organic Al complexation in stream water

- At $\mathrm{pH}<6.7$ inorganic monomeric Al is composed almost entirely of fluoride complexes

- Inorganic monomeric Al complexed with fluoride reaches levels harmful to fish 


\section{Impact of fluoride on Al abundance and speciation in boreal streams}

Tobias Berger ${ }^{a^{*}}$, Frédéric A. Mathurin ${ }^{a}$, Jon Petter Gustafsson ${ }^{b, c}$, Pasi Peltola ${ }^{a}$, Mats E. Åström ${ }^{\mathrm{a}}$

${ }^{\mathrm{a} D e p a r t m e n t ~ o f ~ B i o l o g y ~ a n d ~ E n v i r o n m e n t a l ~ S c i e n c e, ~ L i n n a e u s ~ U n i v e r s i t y, ~ S E-391 ~} 82$ Kalmar, Sweden

${ }^{\mathrm{b}}$ Department of Soil and Environment, Swedish University of Agricultural Sciences, Box 7014, SE-750 07 Uppsala, Sweden

'Division of Land and Water Resources Engineering, KTH Royal Institute of Technology, SE-

10044 Stockholm, Sweden

\section{Appendix A. Equilibrium constants used in Visual MINTEQ modelling}

\section{Table A1}

Solubility constants and enthalpies of reaction for the solid phases considered.

\begin{tabular}{|l|c|c|c|}
\hline Solid & Reaction & $\log K_{\mathrm{s}}$ & $\Delta \boldsymbol{H}_{\mathrm{r}}\left(\mathrm{kJ} \mathrm{mol}^{-1}\right)$ \\
\hline $\mathrm{Al}(\mathrm{OH})_{3}(\mathrm{~s})$ & $\mathrm{Al}(\mathrm{OH})_{3}(\mathrm{~s})+3 \mathrm{H}^{+} \leftrightarrow \mathrm{Al}^{3+}+3 \mathrm{H}_{2} \mathrm{O}$ & $8.29^{\mathrm{a}}$ & $-105^{\mathrm{a}}$ \\
Ferrihydrite & $\mathrm{Fe}(\mathrm{OH})_{3}(\mathrm{~s})+3 \mathrm{H}^{+} \leftrightarrow \mathrm{Fe}^{3+}+3 \mathrm{H}_{2} \mathrm{O}$ & $2.69^{\mathrm{b}}$ & $-100.4^{\mathrm{c}}$ \\
\hline
\end{tabular}

${ }^{a}$ Gustafsson et al. (2001).

${ }^{\mathrm{b}}$ Smith et al. (2003).

'Liu and Millero (1999). 


\section{Table A2}

Solubility constants and enthalpies of reaction for the inorganic Al complexes considered.

\begin{tabular}{|c|c|c|c|}
\hline Species & Reaction & $\log K$ & $\left.\Delta H_{\mathrm{r}}(\mathrm{kJ} \mathrm{mol})^{-1}\right)$ \\
\hline $\mathrm{AlOH}^{2+}$ & $\mathrm{Al}^{3+}+\mathrm{H}_{2} \mathrm{O} \leftrightarrow \mathrm{AlOH}^{2+}+\mathrm{H}^{+}$ & $-5.00^{\mathrm{a}}$ & $-47.8^{a}$ \\
\hline $\mathrm{Al}(\mathrm{OH})^{2+}$ & $\mathrm{Al}^{3+}+2 \mathrm{H}_{2} \mathrm{O} \leftrightarrow \mathrm{Al}(\mathrm{OH})_{2}^{+}+2 \mathrm{H}^{+}$ & $-10.29^{a}$ & $-122.5^{a}$ \\
\hline $\mathrm{Al}(\mathrm{OH})_{3}$ & $\mathrm{Al}^{3+}+3 \mathrm{H}_{2} \mathrm{O} \leftrightarrow \mathrm{Al}(\mathrm{OH})_{3}+3 \mathrm{H}^{+}$ & $-16.69^{a}$ & $-176.3^{a}$ \\
\hline $\mathrm{Al}(\mathrm{OH})_{4}^{-}$ & $\mathrm{Al}^{3+}+4 \mathrm{H}_{2} \mathrm{O} \leftrightarrow \mathrm{Al}(\mathrm{OH})_{4}^{-}+4 \mathrm{H}^{+}$ & $-23.0^{b}$ & $-183.0^{b}$ \\
\hline $\mathrm{AlF}^{2+}$ & $\mathrm{Al}^{3+}+\mathrm{F}^{-} \leftrightarrow \mathrm{AlF}^{2+}$ & $7.01^{\mathrm{a}}$ & $-4.6^{\mathrm{a}}$ \\
\hline $\mathrm{AlF}_{2}^{+}$ & $\mathrm{Al}^{3+}+2 \mathrm{~F}^{-} \leftrightarrow \mathrm{AlF}_{2}^{+}$ & $12.63^{\mathrm{a}}$ & $-8.3^{a}$ \\
\hline $\mathrm{AlF}_{3}$ & $\mathrm{Al}^{3+}+3 \mathrm{~F}^{-} \leftrightarrow \mathrm{AlF}_{3}$ & $16.7^{\mathrm{a}}$ & $-8.7^{\mathrm{a}}$ \\
\hline $\mathrm{AlF}_{4}^{-}$ & $\mathrm{Al}^{3+}+4 \mathrm{~F}^{-} \leftrightarrow \mathrm{AlF}_{4}^{-}$ & $19.8^{\mathrm{a}}$ & $-8.7^{a}$ \\
\hline $\mathrm{AlSO}_{4}^{+}$ & $\mathrm{Al}^{3+}+\mathrm{SO}_{4}^{2-} \leftrightarrow \mathrm{AlSO}_{4}^{+}$ & $3.84^{c}$ & polyn. ${ }^{c}$ \\
\hline $\mathrm{AlH}_{3} \mathrm{SiO}_{4}{ }^{2+}$ & $\mathrm{Al}^{3+}+\mathrm{H}_{4} \mathrm{SiO}_{4} \leftrightarrow \mathrm{AlH}_{3} \mathrm{SiO}_{4}{ }^{2+}+\mathrm{H}^{+}$ & $-2.38^{d}$ & $-66.6^{d}$ \\
\hline
\end{tabular}

${ }^{\mathrm{a}}$ Smith et al. (2003).

${ }^{b}$ Wesolowski, D.J. (1992).

${ }^{c}$ Xiao et al. (2002). A polynomial was used for temperature corrections.

${ }^{d}$ Pokrovski et al. (1996). 


\section{Table A3}

Metal complexation constants to dissolved fulvic acid in the Stockholm Humic Model incorporated in the Visual MINTEQ program 3.0, beta.

\begin{tabular}{|c|c|c|}
\hline Complex & $\log K$ & $\Delta L K_{2}$ \\
\hline $\mathrm{FA}_{2} \mathrm{AlOH}$ & $-9.3^{\mathrm{a}}$ & $1^{a}$ \\
\hline $\mathrm{FA}_{2} \mathrm{Al}^{+}$ & $-4.2^{a}$ & $1^{a}$ \\
\hline $\mathrm{FACa}^{+}$ & $-2.4^{a}$ & $0.3^{\mathrm{a}}$ \\
\hline $\mathrm{FA}_{2} \mathrm{Ca}$ & $-11.3^{a}$ & $0.3^{\mathrm{a}}$ \\
\hline $\mathrm{FAFe}(\mathrm{II})^{+}$ & $-2.0^{\mathrm{a}}$ & $0.3^{\mathrm{a}}$ \\
\hline $\mathrm{FA}_{2} \mathrm{Fe}(\mathrm{III}) \mathrm{OH}$ & $-4.6^{b}$ & $1.7^{b}$ \\
\hline $\mathrm{FA}_{2} \mathrm{Fe}(\mathrm{III})^{+}$ & $-1.68^{b}$ & $1.7^{b}$ \\
\hline FAMg $^{+}$ & $-2.5^{\mathrm{a}}$ & $0.3^{\mathrm{a}}$ \\
\hline \multicolumn{3}{|c|}{$\Delta L K_{2}=$ Distribution term that modifies the strengths of the complexation sites. } \\
\hline \multicolumn{3}{|c|}{$F A=$ fulvic acid } \\
\hline \multicolumn{3}{|c|}{$\begin{array}{l}\text { a Reactions are described by Gustafsson et al. (2007). The constants have been optimised using } \\
\text { the data set of Milne et al. (2003) }\end{array}$} \\
\hline \multicolumn{3}{|c|}{${ }^{\mathrm{b}}$ Constants optimised as explained in Sjöstedt et al. (2010) } \\
\hline
\end{tabular}

\section{References in Appendix A}

Gustafsson, J.P., Persson, I., Kleja, D.B., Van Schaik, J.W.J., 2007. Binding of iron(III) to organic soils: EXAFS spectroscopy and chemical equilibrium modeling. Environmental Sci. \& Technol., 41(4): 1232-1237.

Gustafsson, J.P., Berggren, D., Simonsson, M., Zysset, M., Mulder, J., 2001. Aluminium solubility mechanisms in moderately acid Bs horizons of podzolized soils. Eur. J. of Soil Sci., 52(4): 655-665.

Liu, X.W., Millero, F.J., 1999. The solubility of iron hydroxide in sodium chloride solutions. Geochimica Et Cosmochimica Acta, 63(19-20): 3487-3497.

Milne, C.J., Kinniburgh, D.G., Van Riemsdijk, W.H., Tipping, E., 2003. Generic NICA-Donnan model parameters for metal-ion binding by humic substances. Environmental Sci. \& Technol., 37(5): 958-971. 
Pokrovski, G.S., Schott, J., Harrichoury, J.C., Sergeyev, A.S., 1996. The stability of aluminum silicate complexes in acidic solutions from 25 to 150 degrees C. Geochimica Et Cosmochimica Acta, 60(14): 2495-2501.

Sjöstedt, C.S., Gustafsson, J.P., Köhler, S.J., 2010. Chemical Equilibrium Modeling of Organic Acids, $\mathrm{pH}$, Aluminum, and Iron in Swedish Surface Waters. Environmental Sci. \& Technol., 44(22): 8587-8593.

Smith et al., 2003. NIST Critically Selected Stability Constants of Metal Complexes Database. Version 7.0, Gaithersburg, VA, USA.

Wesolowski, D.J., 1992. Aluminium speciation and equilibria in aqueous-solution .1. The solubility of gibbsite in the system Na-K-Cl-OH-Al(OH)4 from 0-degrees to 100 degrees-C. Geochimica Et Cosmochimica Acta, 56(3): 1065-1091.

Xiao, C.B., Wesolowski, D.J., Palmer, D.A., 2002. Formation quotients of aluminum sulfate complexes in NaCF3SO3 media at 10, 25, and 50 degrees $\mathrm{C}$ from potentiometric titrations using a mercury/mercurous sulfate electrode concentration cell. Environmental Sci. \& Technol., 36(2): 166-173. 